\title{
Penerapan Model Pembelajaran Vee Map Melalui Belajar Kooperatif di SMA Negeri 2 Padang
}

\author{
Oleh \\ Masril \\ Jurusan Fisika FMIPA UNP
}

\begin{abstract}
ABSTRAK
Banyak masalah yang ditemui dalam proses pembelajaran fisika di sekolah menengah, salah satu diantaranya adalah siswa sulit untuk memahami konsep-konsep fisika secara benar. Oleh sebab itu salah satu solusi yang ditawarkan adalah menggunakan model pembelajaran Vee Map. Secara teoritis model pembelajaran Vee Map dapat merangsang dan menggalakkan siswa untuk aktif berfikir dalam menemukan konsep melalui proses menghubungkan ide-ide baru dengan ide yang telah ada pada diri siswa. Oleh sebab itu tujuan penelitian ini adalah untuk mengetahui pengaruh penerapan model Pembelajaran Vee Map di SMAN 2 Padang.

Untuk mencapai tujuan penelitian di atas, dilakukan penelitian eksperimen semu dengan populasi adalah siswa kelas X SMAN 2 Padang dan sampel diambil dua kelas dengan teknik cluster random sampling. Kelas yang terpilih sebagai sampel dijadikan kelas eksperimen dan kelas kontrol.

Berdasarkan hasil analisis data tes akhir didapatkan bahwa nilai rata-rata hasil belajar kelas eksperimen $(67,2)$ lebih besar dari nilai rata-rata kelas kontrol $(62,11)$. Dengan menggunakan statistik uji $\mathrm{t}$ pada taraf nyata 0,05 menunjukkan bahwa $\mathrm{t}_{\text {Hitung }}$ $(2,203)>t_{\text {Tabel }}(1,9943)$. Hal ini berarti bahwa terdapat pengaruh yang berarti penerapan model pembelajaran Vee Map di kelas X SMAN 2 Padang.
\end{abstract}

KEY WORDS : model pembelajaran, vee map, hasil belajar

\section{PENDAHULUAN}

Peranan fisika sangat penting dalam pengembangan kreativitas, kemampuan berpikir, dan imajinasi manusia untuk membentuk sumber daya manusia yang berkualitas. Fisika bukan hanya sekedar kumpulan fakta dan prinsip, tetapi juga bagaimana cara-cara memperoleh fakta dan prinsip itu serta sikap fisikawan dalam melakukannya (Supriono 2003: 8). Kreativitas dan penalaran yang tinggi untuk menyelesaikan suatu persoalan sangat dituntut dalam mempelajari fisika. Dalam pelajaran fisika di sekolah, Depdiknas (2002: 2) mendefinisikan :

Mata pelajaran fisika adalah salah satu mata pelajaran sains yang dapat mengembangkan kemampuan berpikir analitis deduktif dengan menggunakan berbagai peristiwa alam dan penyelesaian masalah baik secara kualitatif maupun secara kuantitatif dengan menggunakan matematika serta dapat mengembangkan pengetahuan, keterampilan dan sikap percaya diri. 
Berdasarkan definisi di atas, dapat diartikan bahwa mata pelajaran fisika dapat membantu mengembangkan kemampuan berfikir, mengembangkan pengetahuan, keterampilan dan sikap percaya diri.

Untuk memperoleh hasil belajar yang baik dalam fisika, siswa seharusnya dapat mengembangkan kemampuan berpikirnya dan tidak hanya sekedar menghafal pelajaran, tetapi dalam pembelajaran siswa harus mampu membangun pengetahuannya, aktif dalam proses pembelajaran, serta mampu memahami konsep-konsep yang diajarkan sehingga siswa dapat memecahkan dan mencari solusi dari suatu persoalan.

Samri (1996: 12) mengatakan "jika siswa memiliki kemampuan berfikir tingkat mahir, maka mereka memiliki kemampuan mengebolarasi suatu konsep sehingga menghasilkan pemahaman terhadap konsep tersebut, akhirnya dapat meningkatkan hasil belajar siswa". Pelaksanaan proses belajar mengajar seharusnya guru dituntut untuk mengkondisikan dan memotivasi siswa dalam belajar berfikir sehingga dapat mencapai tujuan pendidikan berupa perubahan tingkah laku serta mampu menerapkan ilmu tersebut dalam kehidupan sehari-hari.

Berdasarkan dengan masalah di atas, maka salah satu bentuk alternatif strategi pengajaran dan pembelajaran yang dapat diterapkan adalah menggunakan model pembelajaran Vee Map. Vee map as a way depicting what students know and the "route to new and future knowledge" (Roth dan Verechaka(1993) dalam Bromley, Karen, dkk. 1995: 100): Model pembelajaran vee map dimulai dengan cara memfokuskan perhatian siswa pada apa yang sudah mereka ketahui sebelum melakukan percobaan, siswa kemudian membuat pertanyaan, merencanakan dan melakukan penelitian, dan menganalisis data. Melalui menganalisis, mereka akan memperoleh pengetahuan baru yang juga berhubungan dengan pengetahuan yang telah dimiliki sebelumnya.

Menurut pandangan Gowin 1999 (dalam Wahidin. 2003: 3), Vee Map dapat dirumuskan sebagai suatu diagram visual berbentuk "huruf V" yang mengandung unsurunsur (konseptual dan metodologi) tertentu sebagai panduan untuk menyelesaikan suatu masalah secara ilmiah. Bob Gowin mengembangkan Vee Map sebagai salah satu cara untuk membantu dalam memahami makna hubungan antara peristiwa, proses atau objek. Diagram ini menitik beratkan pada peranan penting dari konsep belajar dan ingatan. Oleh karena itu, penggunaan Vee Map bertujuan membantu proses inkuiri tentang bagaimana struktur kognitif terbentuk pada diri siswa (Masril, 2002). 
Seperti disebutkan di atas, bahwa Vee Map mengandung unsur-unsur yaitu; titik persoalan, objek, peristiwa, konsep, teori, prinsip, transformasi, tuntutan pengetahuan. Selain itu, Vee Map juga dapat mengandung unsur yang lebih luas dan kompleks seperti tuntutan nilai dan falsafah hidup. Contoh Vee Map dalam pembelajaran fisika seperti gambar berikut :

Gambar 1. Vee Map dalam belajar fisika tentang pembiasan cahaya.

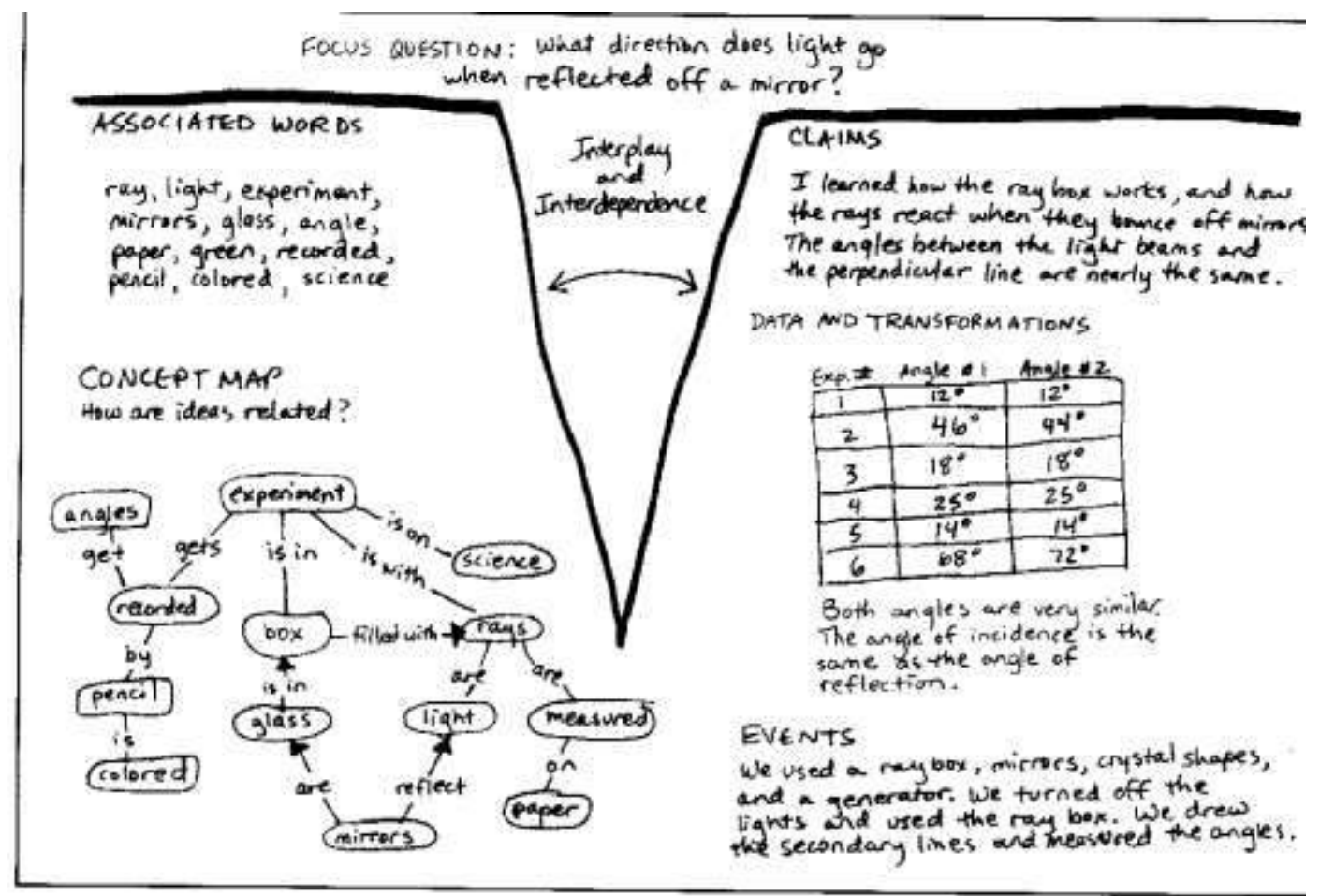

Model pembelajaran Vee Map ini dilakukan melalui proses menghubungkan ideide baru siswa dengan ide yang telah ada pada diri siswa. Ide itu diperoleh melalui analisis bacaan, tugas-tugas akademik, supaya terjadi interaksi sosial antara siswa dan guru serta metakognitif (Kyle et al. 1988; dkk). Dalam pembelajaran Vee Map lebih ditekankan dalam proses berfikir untuk menemukan pengetahuan yang baru dan penguat pangetahuan yang ada dalam diri siswa.

Sehubungan dengan itu, beberapa pakar seperti Bloom (1956); Ausubel (1968); Gagne (1968); Vygotsky (1978); Novak dan Gowin (1984,1999); Philips (1981); Zahorik (1995); Fellow (1994), dan Beyer $(1988,1997)$ dalam Bromley, Karen, dkk. (1995) membahas tentang pembelajaran dan kecakapan berfikir. Kecakapan berfikir merupakan gambaran dari proses berfikir rasional yang mengandung sekumpulan proses mental dari yang sederhana menuju yang kompleks. Berfikir merupakan keterampilan dalam 
menggunakan fikiran, kecakapan ini meliputi menggali informasi, menggambil keputusan secara cerdas, dan memecahkan masalah secara tepat dan baik (Bloom dalam Ngalim Purwanto, 1984). Depdiknas (2004: 10) diungkapkan "kecakapan berfikir (thinking skill) mencangkup: kecakapan menggali informasi, kecakapan mengolah informasi, kecakapan mengambil keputusan dan kecakapan memecahkan masalah".

Untuk mengoptimalkan pembelajaran Vee Map ini, diperlukan pembelajaran yang bernuansa kolaborasi karena kolaborasi dapat mengakomodasi keragaman peserta didik dan akan menghasilkan sinergi yang pada akhirnya bermuara pada proses dan produk belajar yang optimal (Dunlap \& Grabinger, 1996). Salah satu bentuk pembelajaran yang memiliki aspek kolaborasi adalah pembelajaran yang berorientasi model belajar kooperatif (Bennett, et al., 1991; Dunlap \& Grabinger, 1996; Slavin ; 1995). Bekerja secara kooperatif menyediakan peluang pada siswa untuk lebih mungkin dapat memecahkan masalah kompleks yang seringkali tidak akan mereka capai bila bekerja sendirian.

Karena begitu pentingnya Pembelajaran Vee Map dalam pembelajaran, maka rumusan masalah dalam penelitian ini adalah : Apakah ada pengaruh penerapan Model Pembelajaran Vee Map Melalui Belajar Kooperatif di SMA Negeri 2 Padang.

\section{Tujuan Penelitian}

Penelitian ini bertujuan untuk mengetahui: Pengaruh penerapan model pembelajaran vee map dalam meningkatkan hasil belajar Fisika di SMA Negeri 2 Padang.

\section{Hipotesis Penelitian}

Untuk menemukan jawaban sementara dari permasalahan penelitian, maka dapat dirumuskan hipotesis kerja dalam penelitian ini yaitu "Terdapat pengaruh yang berarti pembelajaran menggunakan model Pembelajaran Vee Map melalui pembelajaran kooperatif terhadap peningkatan hasil belajar fisika siswa di SMA N 2 Padang".

\section{METODE PENELITIAN}

Penelitian ini bersifat eksperimental semu dengan rancangan penelitian menggunakan Randomized Control Group Only Design. Pada penelitian ini sample dibagi menjadi dua kelompok yaitu kelompok eksperimen dan kelompok kontrol. Siswa pada kelas eksperimen diberikan perlakuan dengan pembelajaran menggunakan model 
Pembelajaran Vee Map sedangkan kelas kontrol dilakukan dengan pembelajaran secara biasa sesuai dengan kurikulum.

\section{Populasi dan Sampel}

Populasi dalam penelitian adalah siswa kelas X SMA N 2 Padang yang terdaftar pada tahun ajaran 2007 / 2008, sedangkan sampel merupakan bagian dari populasi yang diambil sebagai sumber data dan dapat mewakili seluruh populasi. Untuk memperoleh sampel yang representatif digunakan teknik cluster random sampling. Teknik ini merupakan teknik pengambilan sampel secara kelompok-kelompok individu yang telah tersedia sebagai populasi. Dari populasi yang ada diambil dua kelompok sampel yang homogen sebagai kelas kontrol dan kelas eksperimen.

Teknik analisis data yang digunakan untuk menentukan apakah hasil belajar fisika siswa kelas eksperimen lebih baik daripada kelas kontrol digunakan uji kesamaan dua ratarata dalam uji $t$. Kriteria pengujian hipotesis adalah membandingkan harga $t_{\text {hitung }}$ dengan $\mathrm{t}_{\text {tabel}}$, yang terdapat pada tabel distribusi $\mathrm{t}$, jika nilai $-\mathrm{t}_{1-1 / 2 \alpha}<\mathrm{t}<\mathrm{t}_{1-1 / 2 \alpha}$ pada taraf signifikan 0,05 maka Ho diterima sedangkan untuk harga $\mathrm{t}<-\mathrm{t}_{1-1 / 2 \alpha}$ dan $\mathrm{t}>\mathrm{t}_{1-1 / 2 \alpha}$. Ho ditolak, atau dikatakan juga bahwa Hi diterima. (Sudjana, 2002: 239).

\section{HASIL DAN PEMBAHASAN}

Berdasarkan penelitian yang telah dilakukan pada kelas sampel, didapat hasil belajar fisika siswa yang diperoleh setelah proses belajar mengajar berlangsung. Data aspek kognitif diambil setelah melakukan proses belajar mengajar di kelas eksperimen dan kontrol. Tes akhir yang diberikan berbentuk tes objektif dengan jumlah soal 25 butir. Deskripsi data yang diperoleh dari hasil penelitian dapat dilihat dalam tabel 1 .

Tabel 1. Deskripsi Data Hasil Penelitian.

\begin{tabular}{|c|c|c|}
\hline & Kelas Eksperimen & Kelas Kontrol \\
\hline Jumlah siswa yang ikut tes & 39 & 38 \\
\hline Nilai rata-rata & 67,2 & 62,11 \\
\hline Standar Deviasi & 10,70 & 9,52 \\
\hline Varians & 114,67 & 90,58 \\
\hline Nilai Maksimum & 88 & 84 \\
\hline Nilai Minimum & 48 & 44 \\
\hline
\end{tabular}


Deskripsi data yang diperoleh dalam Tabel 1 digambarkan dalam gambar 2.

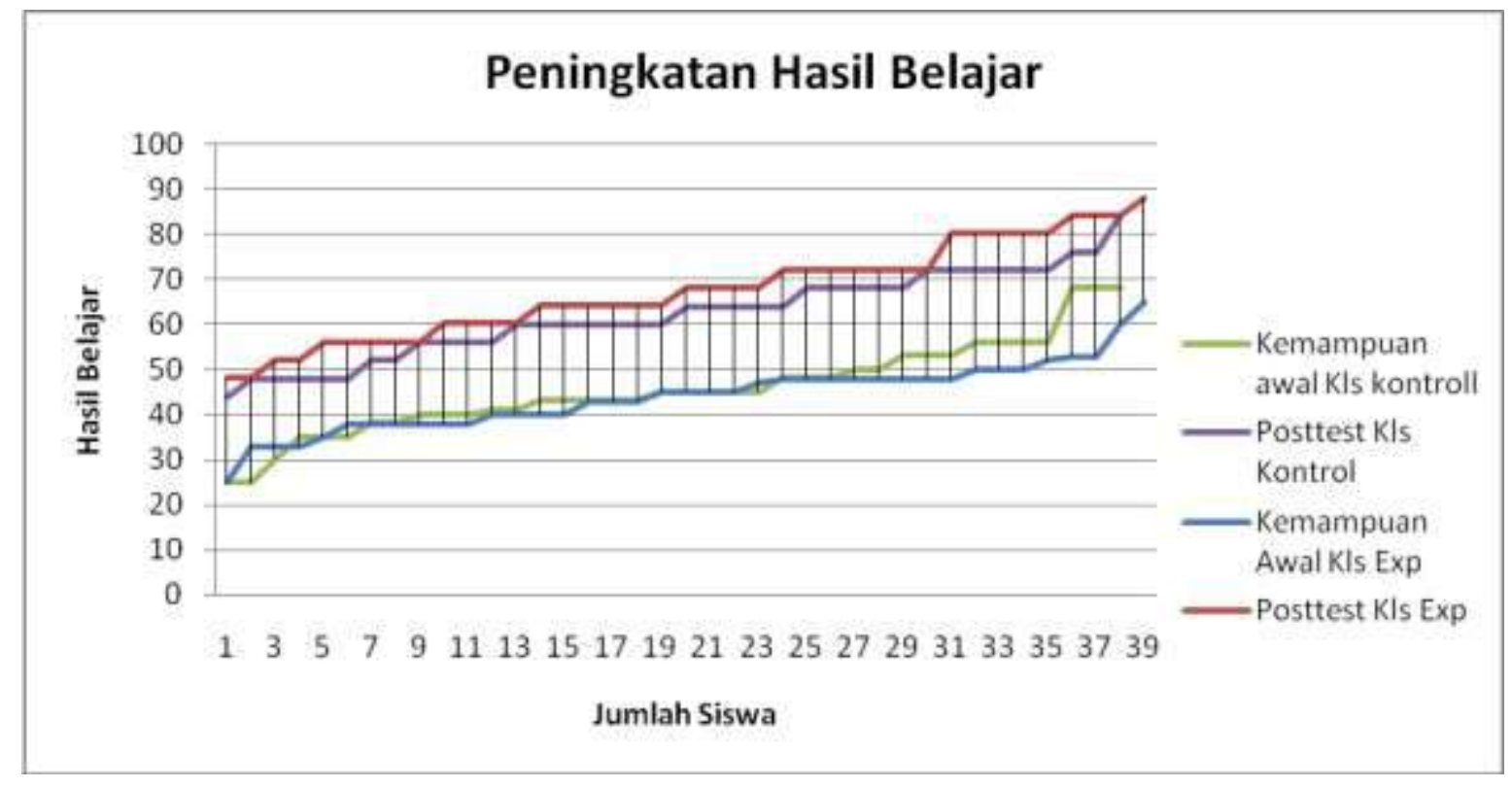

Gambar 2. Peningkatan Hasil Bealajar Siswa Sebelum dan Sesudah Eksperimen

Dari analisis uji normalitas dan uji homogenitas, diperoleh data kedua kelas terdistribusi normal dan memiliki varians yang homogen maka untuk uji kesamaan dua rata-rata digunakan uji t. Dari hasil perhitungan diperoleh $t_{\text {hitung }}=2,203$, sedangkan pada $\alpha$ $=0,05$ dengan $\mathrm{dk}=75$ diperoleh $\mathrm{t}_{\text {tabel }}=1,9943$. Kriteria pengujian terima Ho adalah $\left(-\mathrm{t}_{1-}\right.$ $\left.{ }_{1 / 2 \alpha}<\mathrm{t}<\mathrm{t}_{1-1 / 2 \alpha}\right)$, maka berdasarkan hal ini, dapat dilihat bahwa harga $\mathrm{t}_{\text {hitung }}$ berada diluar daerah penerimaan Ho. Hal ini berarti bahwa hipotesis Ho ditolak dan hipotesis kerja (Hi) diterima.

\section{PEMBAHASAN}

Dari hasil analisis nilai tes akhir diperoleh nilai rata-rata kelas eksperimen 67,20 dan kelas kontrol 62,11. Hal ini menunjukkan bahwa terdapat perbedaan hasil belajar antara kelas eksperimen dan kelas kontrol yang disebabkan oleh pengaruh perlakuan yang diberikan pada siswa di kelas eksperimen, dengan arti kata pembelajaran Vee Map dapat meningkatkan hasil belajar fisika siswa. Secara kajian teori, pembelajaran Vee Map dapat membantu siswa menemukan konsep atau pengetahuan dengan sendirinya melalui percobaan berdasarkan pertanyaan yang telah dirancang yaitu Focus Question. Sehingga siswa tidak perlu lagi mendengarkan penjelasan guru secara panjang lebar tapi siswa mengalami sendiri dalam melakukan percobaan yang dibantu dengan LKS. Selain itu, di 
dalam pembelajaran Vee Map siswa dilatih bagaimana menemukan permasalahan, mencari informasi atau mengumpulkan ide-ide (Assosiated words) sampai memecahkan permasalahan atau menemukan konsep dan pengetahuan (Knowledge Claim). Disinilah siswa dilatih untuk mengembangkan kecakapan berfikirnya. Berarti dengan pembelajan Vee Map telah melatih dan mengajarkan kepada siswa bagaimana menemukan pengetahuan atau menemukan konsep dengan sendirinya sehingga suasana dalam belajar akan menjadi aktif sehingga dapat membantu meningkatkan hasil belajar.

Berdasarkan pengamatan selama penelitian berlangsung, pelaksanaan pembelajaran Vee Map ini selain membantu meningkatkan kecakapan berfikir siswa tetapi juga menjadikan siswa aktif, kreatif dan kritis dalam memahami pelajaran, tidak semata-mata menghafal tetapi siswa sendirilah yang mencari konsep berdasarkan percobaan atau eksperimen sesuai dengan permasalahan yang telah dirancang. Melalui eksperimen/percobaan tersebut, membuat siswa berusaha menalar dan menafsirkan apa, mengapa, dan bagaimana gejala-gejala yang sedang diamatinya, sehingga pada akhirnya mereka berusaha memperoleh pengetahuan/konsep.

Selama penelitian berlangsung kecakapan berfikir yang meningkat antara lain kecakapan menggali informasi yaitu dalam mengumpulkan ide-ide (Assosiated words) dimana siswa telah mampu mengumpulkan ide-ide, mengumpulkan pengetahuan awal dan mencari sumber lain yang berhubungan dengan pertanyaan yang sudah dirancang. Setelah ide-ide tersebut dikumpulkan siswa membuat ide-ide tersebut ke dalam suatu peta konsep (konsep map), dengan dibuatnya ke dalam sebuah peta konsep siswa akan mengetahui lagi ide-ide apa yang belum ada sehingga siswa berusaha untuk menggali informaasi lagi. Kecakapan lain yang meningkat adalah kecakapan mengolah informasi. Di dalam melakukan percobaan/eksperimen siswa telah mampu merancang sendiri percobaan setelah mendapatkan data mentah dari percobaan, dengan menghubungkan ide-ide awal dengan data yang diperolah dari hasil percobaan siswa telah mampu mengolah informasi tersebut sampai mendapatkan konsep atau pengetahuan dan disinilah timbul kecakapan memecahkan masalah dari siswa. Dengan meningkatnya kecakapan berfikir tersebut maka telah terbukti bahwa pembelajaran Vee Map mempengaruhi aspek kognitif yaitu meningkatnya hasil belajar pada kelas eksperimen.

Namun selama penelitian dilaksanakan terdapat kelemahan-kelemahan diantaranya keterbatasan waktu yang dimiliki siswa untuk menyelesaikan permasalahan yang telah dikemukakannya dan siswa terlalu banyak dalam satu kelas. Kemudian, sarana belajar 
yang kurang mendukung seperti peralatan labor yang kurang lengkap dan buku paket siswa yang masih terbatas dapat menurunkan motivasi belajar siswa. Sehingga jika dilihat nilai kedua kelas terlihat bahwa pembelajaran yang dilakukan belum memberikan hasil yang diharapkan, dan pembelajaran belum tuntas secara klasikal.

Dalam pelaksanaannya guru dituntut untuk mempersiapkan pembelajaran secara baik terutama persiapan pembuatan lembaran kerja siswa sebagai penuntun siswa yaitu tentang langkah-langkah pembelajaran Vee Map, sehingga hasil yang diperoleh benarbenar hasil dari perlakuan.

\section{KESIMPULAN}

1. Terdapat pengaruh penerapan pembelajaran Vee Map terhadap hasil belajar fisika siswa di kelas X SMAN 2 Padang, hal ini ditunjukkan dengan adanya perbedaan hasil belajar untuk kedua kelas sampel.

2. Pembelajaran Vee Map cocok digunakan untuk Meningkatkan Kecakapan Berfikir Siswa.

\section{SARAN}

1. Dengan terdapatnya pengaruh yang berarti dari penerapan Pembelajaran Vee Map Terhadap Hasil Belajar Fisika Siswa maka Vee Map dapat digunakan sebagai alternatif bagi guru-guru dalam usaha meningkatkan hasil belajar fisika siswa dan membantu meningkatkan keterampilan berfikir siswa.

2. Diharapkan ada penyempurnaan oleh peneliti selanjutnya dengan mengoptimalkan penggunaan pembelajaran Vee Map dengan materi yang berbeda. 


\section{DAFTAR PUSTAKA}

Bennett, el al., 1991. Dunlap \& Grabinger, 1996; Slavin, 1994; 1995), Cooperative Learning : Where Heart Meets Mind, Proffesional Development Associates, Bothell, Washington.

Bromley, Karen, dkk. 1995. Graphic Organizers. New York : Scholastic.

Depdiknas. (2002). Kompetensi Dasar Mata Pelajaran Fisika SMA \& MA. Jakarta: Balitbang.

Depdiknas. (2004). Kurikulum 2004 SMA. Pedoman Khusus Pengembangan Silabus dan Penilaian Mata Pelajaran Fisika. Jakarta: Depdiknas. Ditjen. Dikdasmen. Ditdikmenum.

Dunlap, J. C., \& Grabinger, R. S. 1996. Rich Environments For Active Learning In The Higher Education Classroom. Dalam Wilson, B. G. (Ed.): Constructivist learning environment: Case studies in instructional design, pp. 65-82. New Jersey: Educational Technology Publications Englewood Clifs.

Masril, Nur Asma, 2002, Pengungkapan Miskonsepsi Siswa Menggunakan Force Concept Inventory Dan Certainty Of Response Index, Jurnal Fisika HFI Suplemen Prosiding B Volume 5. Pages 0559

Ngalim Purwanto. (1984). Dasar-dasar Evaluasi Pendidikan. Jakarta : PT. Bumi Aksara. Oemar Hamalik. (2001). Prosees Belajar dan Pembelajaran. Bandung: Ganesha.

Roth, W.-M.,\& Verechaka, G. (1993, Januari). Plotiing a course with vee maps: direct your students on the road to inquiry science. Science $\&$ children.

http://www.educ.uvic.ca/faculty/mroth/teaching/445/Veemap SC3.gif. Diakses 10 mai 2008.

Sudjana. (2002). Metode Statistik. Bandung : Tarsito

Suharsimi Arikunto. (2005). Dasar Evaluasi Pendidikan. Edisi Revisi. Jakarta: Bumi Aksara.

Supriyono Koes. (2003). Strategi Pembelajaran Fisika. rev. ed. Malang : JICA

Wahidin. (2003). Penggunaan Peta Vee dalam Pembelajaran Kimia Bagi Meningkatkan Kemahiran berfikir Sains. Ciamis, Wilayah Jawa Barat. http://nucim.org/dina/diskursus/diskursus_detail.asp? . Diakses 15 Mai 2008. 
